\title{
Government Expenditure on Agricultural Sector and Economic Growth in Nigeria (1981 - 2010)
}

\author{
Ishola S. Ademola ${ }^{1}$, Olaleye S.O $(\mathrm{PhD})^{2}$, Ajayi E.Olusuyi ${ }^{3}$ Femi Edun $(\mathrm{PhD})^{4}$ \\ ${ }^{1}$ (Department, Internal Control \& Audit/ National Mirror Newspaper, Lagos, Nigeria) \\ ${ }_{2}^{2}$ (Department of Economics, Faculty of Social Sciences / Lagos State University, Nigeria) \\ ${ }^{3}$ (Department of Economics \& Accounting College of Management Sciences / Bells University, Otta, Ogun \\ State, Nigeria) \\ ${ }^{4}$ (Department of Economics, Faculty of Social Sciences / Lagos State University, Nigeria)
}

\begin{abstract}
The contribution of the agricultural sector of the economy cannot be over emphasized when considering its role in building grounds for development, its employment potentials and impacts on the economy. This study is set forth to explore the average contribution of the agricultural sector to the national earning of Nigeria over the years, using a time series data from 1981 to 2010 sourced from the Central bank of Nigeria. The empirical perspective of this paper applied the unit root test and co integration, relying on the theoretical backing posited by Solow. It was found that a significant relationship exist between government expenditure in the agricultural sector and the economic growth of Nigeria.
\end{abstract}

Keywords - Economic Growth, Government Expenditure, Gross Domestic Product, Agricultural Sector

\section{INTRODUCTION}

I $\mathrm{n}$ the world today, agricultural sector acts as the catalyst that accelerates the pace of structural transformation and diversification of the economy, enabling the country to fully utilize its factor endowment, depending less on foreign supply of agricultural product or raw materials for its economic growth, development and sustainability.

The contribution of the agricultural sector of the economy cannot be over emphasized when considering its role in building grounds for development, its employment potentials and financial impacts on the economy. Apart from laying solid foundation for the economy, it also serves as import substituting sector, providing ready market for raw materials and intermediate goods. Thus, putting it in Aderibigbe's (2004) idea; the manufacturing industry contributes significantly to the nation's economic development by: increasing government revenue through tax; improving the standard of living; infrastructural growth; contribution to Gross National Products (GNP);employment generation; enhance manpower development; etc.

So far, it has been argued that the faster trend through which a nation can achieve sustainable economic growth and development is neither by the level of its endowed material resources, nor that of its vast human resources, but technological innovation, enterprise development (commercial farming of various types inclusive) and industrial capacity.

In the Nigerian experience, the downturn of the global oil market of the early 1980s and the sharp decline in foreign exchange earnings have adversely affected economic growth and development in Nigeria coupled with the global financial crisis that rocked the world economies. Problems particular to the economy of Nigeria include; excessive dependence on imports for consumption and capital goods, dysfunctional social and economic infrastructure, unprecedented fall in capacity utilization rate in industry and neglect of the agricultural sector, among others. These have resulted in fallen incomes and devalued standards of living amongst Nigerians (Anyanwu, 2004). Although the structural adjustment programme (SAP) was introduced in 1986 to address these problems, no notable improvement has taken place. From a middle income nation in the 1970s and early 1980s, Nigeria is today among the 30 poorest nations in the world.

In view of this, the question is; does the agricultural sector 'ceteris paribus' has impact in the economic growth of the nation in view of the Vision 20;2020. The statement to be set to test in this paper is to examine whether there is a significant relationship between agricultural sector and economic growth.

This study, hence, is set forth, using a time series data from 1981 to 2010 sourced from the Central Bank of Nigeria, to explore the average contribution of the agricultural sector to the national earning of Nigeria over the years, say ceteris paribus, what will be the fortune of the manufacturing sector in Nigeria. The empirical perspective of this paper applied unit root test and co-integration, relying on the theoretical backing posited by Solow. 


\section{LITERATURE REVIEW}

Agriculture is the art and science of crop and livestock production. In its broadest sense, agriculture comprises the entire range of technologies associated with the production of useful products from plants and animals, including soil cultivation, crop and livestock management, and the activities of processing and marketing. The term agribusiness has been coined to include all the technologies that mesh in the total inputs and outputs of the farming sector. In this light, agriculture encompasses the whole range of economic activities involved in manufacturing and distributing the industrial inputs used in farming: the farm production of crops, animals and animal products, the processing of there materials into finished products and the provision of products at a time and place demanded by consumers.(Allen,2000:1-26)Agriculture was the key development that led to the rise of human civilization, with the husbandry of domesticated animals and plants (i.e., crops) creating food surpluses that enabled the development of more densely populated and stratified societies. Agriculture encompasses a wide variety of specialties and techniques, including ways to expand the lands suitable for plant raising, by digging water-channels and other forms of irrigation. Cultivation of crops on arable land and the pastoral herding of livestock on rangeland remain at the foundation of agriculture. In the past century there has been increasing concern to identify and quantify various forms of agriculture (e.g. permaculture or organic agriculture) and intensive farming (e.g. industrial agriculture).Interestingly, the Nigerian economy, during the first decade after independence could reasonably be described as an agricultural economy because agriculture served as the engine of growth of the overall economy (Ogen, 2003:231-234). From the standpoint of occupational distribution and contribution to the GDP, agriculture was the leading sector. During this period Nigeria was the world's second largest producer of cocoa, largest exporter of palm kernel and largest producer and exporter of palm oil. Nigeria was also a leading exporter of other major commodities such as cotton, groundnut, rubber and hides and skins (Alkali, 197:15-16). The agricultural sector contributed over $60 \%$ of the GDP in the 1960s and despite the reliance of Nigerian peasant farmers on traditional tools and indigenous farming methods, these farmers produced $70 \%$ of Nigeria's exports and $95 \%$ of its food needs (Lawal, 1997:195). However, the agricultural sector suffered neglect during the hey-days of the oil boom in the 1970s. Ever since then Nigeria has been witnessing extreme poverty and the insufficiency of basic food items. Historically, the roots of the crisis in the Nigerian economy lie in the neglect of agriculture and the increased dependence on a mono-cultural economy based on oil. The agricultural sector now accounts for less than $5 \%$ of Nigeria's GDP (Olagbaju and Falola, 1996:263) see table 1 and 11The neglect of the agricultural sector and the dependence of Nigeria on a mono- cultural, crude oil-based economy have not augured well for the well-being of the Nigerian economy. In a bid to address this drift, the Nigerian government as from 1975 became directly involved in the commercial production of food crops. Several large scale agricultural projects specializing in the production of grains, livestock, dairies and animal feeds, to mention but a few were established(Fasipe, 1990: 129-130). Sugar factories were also established at Numan, Lafiagi and Sunti (Lawal, 1997: 196). The Nigerian Agricultural and Co-operative Bank (NACB) were established in 1973 as part of government's effort to inject oil wealth into the agricultural sector through the provision of credit facilities to support agriculture and agro-allied businesses (Olagunju, 2000:98).In spite of these efforts, it is heartrending to note that as from the mid 70s, Nigeria became a net importer of various agricultural products. In 1982 alone, Nigeria imported153,000mt tons of palm oil at the cost of 92 million USD and 55,000mt tons of cotton valued at92 million USD (Alkali, 1997:10). Between 1973 and 1980, a total of 7.07 million tons of wheat, 1.62 million tons of rice and 431,000 tons of maize were imported. Thus, from N47.8 million in the 60s, the cost of food imports in Nigeria rose to N88.2 million in 1970 and N656, 527.0million in 1995 (Alkali, 1997:19-21)

The First National Development Plan (1962-1968) emphasized light industry and assembling activities. The second plan (1970-1975) had a somewhat similar thrust and focus, but the emphasis shifted in the third plan (1975-1980) towards heavy industries. Major projects were initiated in the steel and petroleum refinery sector. For the fourth plan (1980-1985), the broad direction was in consonance with the third: it retained the stress on heavy industries. But several of the grandiose plans were short changed with the onset of the profound economic crisis in the early $1980 \mathrm{~s}$.

Onayemi (2003) put forward that the economy of Nigeria is too dependent on oil and it is not progressing significantly due to inconsistency in macroeconomic policies for the growth of different sectors in the economy. When the government only works to safeguard the oil companies' interests, the price of oil does not remain at an affordable level and the agricultural famers have to pay more for the energy resources they consume in the cultivating of land for crops (i.e. irrigation etc.) and rearing of animal processes. When there is news about the discovery of more crude oil wells in the country, foreign investors start paying attention towards it, resulting in the rise of foreign direct investment (FDI) as well as the employment rate. In this way, the economy of Nigeria is determined by oil production and oil prices. It is therefore evident that Nigeria remains highly dependent on oil, which accounts for $80 \%$ or more of its foreign exchange during the last four decades. This policy has proved to be quite harmful to the country because oil price fluctuation has a negative impact on the economy, causing a certain level of instability and uncertainty, aside the fact that the surface of area covered 
can no longer be useful for agricultural activities. The government neglected the non-oil sectors including agricultural sector which has made Nigeria one of the least country in the region.

The fluctuation in oil prices further contributed to the economic instability of the country and poverty was widespread, especially in the rural areas.

Though the Nigerian agricultural sector cannot support economic development in its present condition, it has great potential since Nigeria is one of the most attention-grabbing markets of the region by having over 150 million consumers and millions more consumers in the neighbouring countries. The importance of the agricultural sector is also realized from the fact that private consumption expenditures are significantly increasing in the country up to the rate of 20 to $25 \%$ per year. However, many problems are hindering the growth of the agricultural sector in Nigeria and as a result the country is progressing very slowly towards economic diversification.

Ademola and Atoyebi (2012) summed up the economic scenario in Nigeria and the role of the Agricultural sector by identifying the main hurdles that mostly and historically affect its development and growth. These barriers include insecurity, political instability, market-distorting, state-owned monopolies, weak infrastructure and unavailability of finance while Adenikinju (2003) added excessive bureaucracy and rampant corruption.

Agricultural activities have significant impact on the economy of a nation. In developed economies, for instance, they account for a substantial proportion of total economic activities. This sector is divided into conceptual and theoretical framework:

\section{A. 2.2 Conceptual Framework}

Public expenditure policy is one of the most important instruments of public sector policy. Traditionally, the normative theory of public finance starting with Musgrave, identifies three functions of fiscal policy as: allocation, distribution and stabilization of resources. By means of fiscal policy, any government attempts to ensure effective utilization of limited resources, equitable distribution of income and stability of economic development (Musgrave and Musgrave 1984)The nature of relationship between public expenditure and economic growth via agricultural sector performance has stimulated series of theoretical and empirical studies. Major theoretical work was done by Barro (1988), Barro and Sala i-martin (1995), Devarajan,(1996). In his seminar work, Barro develops a simple endogenous growth model of government spending. In this model, he finds a non-linear relationship between public expenditures which are complementary inputs to private production and a negative relationship between government expenditure and growth of the economy.

\section{B. 2.3 Theoretical Framework}

There has being several theories which had been developed to study economic development. Each of these has its strength and weaknesses with different ideological, theoretical and empirical conclusions. They include; the classic theories of economic development and the endogenous growth model.

The Classic theories have four approaches:

a. The Linear-stages theories was expanciated by; the Rostow's stages of growth and the Harrod- Domar Growth Model.

b. Structural Change Models was administered by the Lewis theory of development and structural change.

c. The international dependency revolution includes the Neoclassical Dependence Model, false paradigm model and the Dualistic-Development Thesis.

d. The traditional neoclassical growth model

The motivation for the endogenous growth model stems from the failure of the neoclassical theories to explain the sources of long-run economic growth. The neoclassical theory does not explain the intrinsic characteristic of economies that causes them to grow over extended period of time. The neoclassical theory focuses on the dynamic process through which capital-labour ratios approach long-run equilibrium. In the absence of external technological change, which is not clearly explained in the neoclassical model, all economies will converge to zero growth.

The neoclassical theory see rising GDP as a temporary phenomenon resulting from technological change or a short-term equilibrating process in which an economy approaches its long run equilibrium. The neoclassical theory credits the bulk of economic growth to a completely independent process of technological progress. According to neoclassical theory, the low capital-labor ratios of developing countries promise exceptionally high rates of return on investment. Based on this premise, it was expected that the freemarket reforms imposed on highly indebted countries by the World Bank and the International Monetary Fund should have prompted higher investment, rising productivity, and improved standards of living. Yet even after the prescribed liberalization of tradeand domestic markets, many LDCs experienced little or nogrowth and failed to attract new foreign investment or tohalt the flight of domestic capital. The anomalous behavior of developingworld capital flows (from poor to rich nations) helped provide the impetus for the development of the concept of endogenous growth or, more simply, the new growth theory. 
The new growth theory represents a key component of the emerging development theory. The new growth theory provides a theoretical framework for analyzing endogenous growth, persistent GNP growth that is determined by the system governing the production process rather than by forces outside that system. In contrast to traditional neoclassical theory, these models hold GNP growth to be a natural consequence of long-run equilibrium.

The principal motivations of the new growth theory are to explain both growth rate differentials across countries and a greater proportion of the growth observed. In particular, endogenous growth theorists seek to explain the factors that determine the rate of growth of GDP that is left unexplained and exogenously determined in the Solow neoclassical growth equation (that is, the Solow residual).

Models of endogenous growth bear some structural resemblance to their neoclassical counterparts, but they differ considerably in their underlying assumptions and the conclusions drawn. The most significant theoretical differences stem from discarding the neoclassical assumption of diminishing marginal returns to capital investments, permitting increasing returns to scale in aggregate production, and frequently focusing on the role of externalities in determining the rate of return on capital investments.

By assuming that public and private investments in human capital generate external economies and productivity improvements that offset the natural tendency for diminishing returns, endogenous growth theory seeks to explain the existence of increasing returns to scale and the divergent long-term growth patterns among countries.

And whereas technology still plays an important role in these models, it is no longer necessary to explain long term growth. A useful way to contrast the new (endogenous) growth with traditional neoclassical theory is to recognize that many endogenous growth theories can be expressed by the simple equation $\mathrm{Y}=\mathrm{AK}$, as in the Harrod-Domar model. In this formulation, A is intended to represent any factor that affects technology, and $\mathrm{K}$ again includes both physical and human capital.

\section{MODEL SPECIFICATION}

There are several researches which have been carried out on the role of agricultural sector in the actualization of economic growth and development. Thus, there seems to be no consensus among these studies on the empirical form the specification of model qualifying the impact of the manufacturing sector can take or follow.

Agreeably, empirical specification of growth oriented model often follows the Solow growth model, which was subsequently modified by Mankiw et al (1992) and is termed the "Augmented Solow growth model. Solow (1956) postulated that economic growth resultant from the accumulation of physical capital and an expansion of the labor force in conjunction with an "exogenous" factor, technological progress, that makes physical capital and labor more productive (Udah2010).

For the purpose of this research work the above will be adopt and build upon, proxing economic development with Gross Domestic Products (GDP); industrialization (proxy by manufacturing sector output); and government expenditure to check government commitment on the provision of infrastructural facilities that will attract investor. With this adjustment incorporated into the model, it can therefore be specified in the form expressed below:

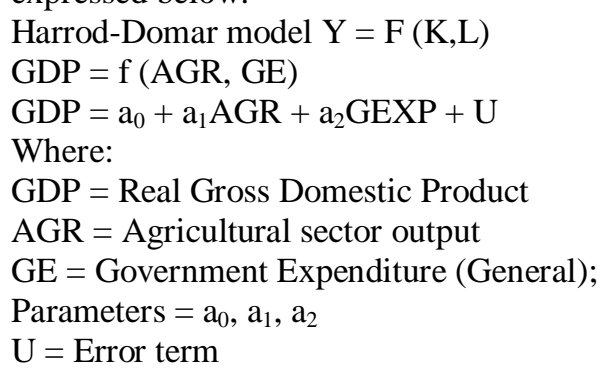

From the specified model equation above, endogenous variable is GDP while the exogenous variables are manufacturing sector output, and government expenditure.

The A prior expectation is $\mathrm{a}_{0}, \mathrm{a}_{1}, \mathrm{a}_{2} \square 0$

\section{FIGURE 1}

\section{PARAMETER ESTIMATION AND INTERPRETATION}

Dependent Variable: GDP

Method: Least Squares

Sample: 19812009

Included observations: 29

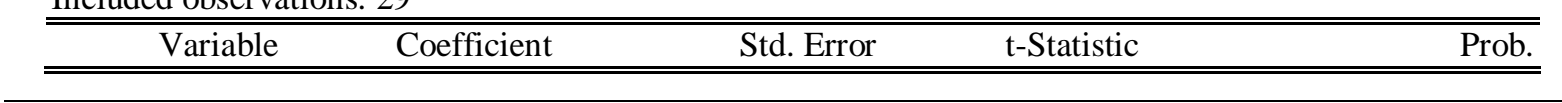


Government Expenditure on Agricultural Sector and Economic Growth in Nigeria (1981 -

\begin{tabular}{|c|c|c|c|c|}
\hline $\mathrm{C}$ & -54963.87 & 202494.4 & -0.271434 & 0.7881 \\
\hline M & 2.444255 & 0.370590 & 6.595577 & 0.0000 \\
\hline GEXP & 1.142150 & 0.972777 & 1.174112 & 0.2506 \\
\hline$\overline{\text { R-squared }}$ & 0.990683 & \multicolumn{2}{|c|}{ "Mean dependent var } & 6168405 \\
\hline Adjusted R-squared & 0.969993 & \multicolumn{2}{|c|}{ S.D. dependent var } & 8772783 \\
\hline S.E. of regression & 877588.4 & \multicolumn{2}{|c|}{ Akaike info criterion } & 30.30238 \\
\hline Sum squared resid & $2.08 \mathrm{E}+13$ & \multicolumn{2}{|c|}{ Schwarz criterion } & 30.44250 \\
\hline Log likelihood & -451.5357 & \multicolumn{2}{|l|}{ F-statistic } & 1.101884 \\
\hline Durbin-Watson stat & 1.100310 & \multicolumn{2}{|c|}{$\operatorname{Prob}($ F-statistic) } & 0.000000 \\
\hline
\end{tabular}

$\mathrm{GDP}=-54963.87+2.444255 \mathrm{AGR}+1.142150 \mathrm{GE}$

$(202494.4) \quad(0.370590) \quad(0.972777)$

The results obtained from the equation estimated show that the explanatory variables explain about 99.06 per cent of the variations in the GDP which is the dependent variable and the proxy of the economic growth. This is judged by the value of the co-efficient of determination (R-squared), more so, the $\mathrm{R}^{2}$ adjusted confirms the $\mathrm{R}^{2}$ at 0.9699 , taking into consideration the degree of freedom and the inclusion or exclusion of a variable. In addition, the results depict no serial auto-correlation problems as reflected in the value of DurbinWatson statistics of 1.100 (Table 1), thus this depicts the presence of positive auto-correlation, which will permit to reject the null hypothesis. However, there is a joint statistical significance of the variables has revealed by the joint test of significance (F-Statistics), to be added to the explanation of the dependent variable at $1 \%$.

Total output in the agricultural sector conforms to the a-priori expectation, but gross domestic product in the agricultural sector shows a negative relationship. It is discovered that a unit change in total output in the agricultural sector increases GDP by the marginal change of 2.444 , the student $t$ statistics shows that total output of the sector is significance statistically different from zero. However, there is a positive relationship between GDP and government expenditure in the manufacturing sector such that GDP will increase by 1.142, this may be subject to government's sumptuous spending in the sector geared toward economic growth. Thus, it exhibits been significant in explaining the variation in GDP.

\section{Recommendation}

\section{RECOMMENDATION, SUMMARY AND CONCLUSION}

It is recommended in the light of this study that, for any nation, to growth, especially Nigeria, the focused expenditure on the agricultural sector should not be underestimated, thus, by all available means, the government should improve and encourage the output of the agricultural sector.

\section{Summary and Conclusion}

This study has investigated the importance of the agricultural sector and government effort in the operation of the sector towards the expansion of the economy. The study used the unit root and co integration test to compliment the ordinary least squares in evaluating the significance or non-significance of the manufacturing sector to the economic growth of the economy (Nigeria).

The result shows that, though there is a significant relationship between the exogenous and endogenous variables, while total output complied with the A Prior expectation, there exists a positive relationship between government expenditure in the sector.

Thus, it is recommended that government should improve and encourage agricultural outputs and improve its expenditure in the agricultural sector geared towards economic growth.

\section{Acknowledgements}

We are grateful to Almighty God who is our Alpha and Omega for granting us the grace to complete this research work and our lovely families.

Special thank goes to our indefatigable mentor and economics department post graduate co-ordinator of Covenant University, Dr. P.O. Alege for rendering us moral and intellectual assistance, advice and untiring effort in guiding us always and other departmental lecturers, most especially, Dr. Lloid, Dr Omoke Philip, Dr. Evans, Professor Nyoung, Professor Ogunrinola (the HOD), Professor Don. Ike, also our colleague, mentor and model in Lagos State University, OJo, Lagos Nigeria.

Our appreciation and unending thanks goes to our role model, Dr. Jimoh Ibrahim (OFR), and also to our brothers Engineer Alfred O. Dairo and Mr Steve Ayorinde, for their constant moral support

Our friends at $\mathrm{PhD}$ class are also appreciated for their constant constructive academic criticisms that serve as our strength today. 


\section{Journal Papers:}

\section{REFERENCES}

[1] Devarajan, Shantayanan, Vinaya Swaroop, Heng-fu Zou (April,1996). The Composition of Public Expenditures and Economic Growth. Journal of Monetary Economics, 37, 313344.

[2] Barro, R. (1988). Economic Growth in a Cross-section of Countries.Quarterly Journal of Economics, 106 (2), $407-43$.

[3] Musgrave, R.A., Musgrave, P. B. (1984). Public Finance inTheory and Practice (4th edition) (pp. 7-12), McGraw-Hill,New York.

[4] Alao R.O., 2006. Fundamentals of Monetary Economics, Muhasmael Ventures, Lagos

[5] Udah, Enang B, (2010): Industrial Development,Electricity Crisis and Economic Performance inNigeria; European Journal of Economics, Finance andAdministrative Sciences ISSN 1450-2887 issue 18 (2010).

[6] Mankiw, G., D. Romer and D. Weil (1992). "A Contribution to the Empirics of Economic Growth": Quarterly Journal of Economics 107, pp 407-37

[7] Onayemi, T. Nigeria Oil: Prices, politics and the people, published in Nigeria Today 2003.

[8] Adenikinju, A. Nigeria's imperative in the new World trade order, workshop report. African economic research consortium (AERC). Nairobi, Kenya and trade policy research and training (TPRTP). Department of economics, University of Ibadan; 2003

[9] Ojowu, N. Speech at Nigeria's imperative in the new World trade Order, workshop report. African economic research consortium (AERC). Nairobi, Kenya and trade policy research and traning (TPRTP). Department of economics, University of Ibadan: 2003

[10] Akinbobola, Ayo (2001) Globalization and its Impact on the Emergent States: An Analysis of itsProblems and Prospects in Brazil and Nigeria Lagos: Concept Publications.Alkali, R.A. (1997) The World Bank and Nigeria: Cornucopia or Pandora Box?

[11] Kaduna:BamettJ and Mahul .O (2007), Weather Index Insurance for Agriculture and Rural Areas inLower-IncomeCountries. American Journal of Agricultural Economics 89(5)Eicher, C., andWitt,L.(eds.)(1964) Agriculture in Economic Development.

[12] HouseJones, EI., and Woolf, S.S. (eds.) (1969) Agrarian Change and Economic Development:The Historical Problems London: Methuen Journal of MDI, Gurgaon

[13] Roberts R.A, (2005). Insurance of Crops in Developed Countries, FAO, Rome. American Economic Review 103(56-78)Kao, K.N (2002) Crop Insurance; Past, Present andFuture An articlepublished in vision, Joly-Decpp13-17Lawal, A.A.(1997)

[14] TheEconomy and the State from thePre-colonial TimestothePresent in Osuntokun, A. and Olukoju, A. (eds.) Nigerian Peoples and Culture.

[15] Ibadan: Davidson. Ogen Olukoya (2003) Patterns of Economic Growth and Development in Nigeria since 1960 in S.O. Arifaloand Gboyega Ajayi (eds.) (2003) 